\title{
The appropriateness of the Design of Experiments to support Lean Six Sigma for variability reduction
}

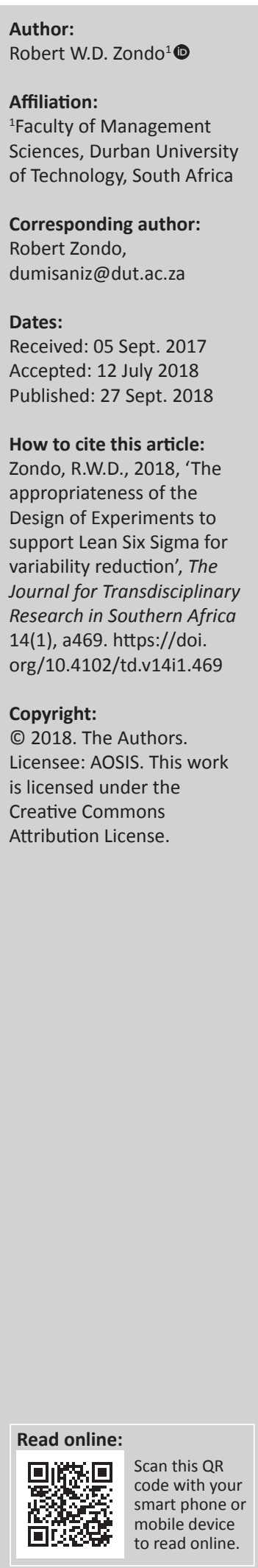

A Design of Experiment (DoE) is a strategy for planning, conducting, analysing and interpreting the experiment so that valid conclusions can be drawn efficiently and economically. It has the ability to reduce product and process variability. Hence, this study examined if DoE is an appropriate tool to support Lean Six Sigma in selected automotive component manufacturing companies in South Africa. The automotive component manufacturing sector uses various tools aimed at reducing variability. This includes Lean Six Sigma. Consequently, companies that participated in the study have (over and above Lean Six Sigma) adopted a DoE strategy. Thus, the study was designed to establish if DoE is an appropriate tool to support Lean Six Sigma. Of the 123 participants identified, 107 completed the questionnaires. Middle managers of four automotive component manufacturing companies in the eThekwini District Municipality participated in the study. The study investigated production and the related experiences of the automotive component manufacturing companies. Descriptive and correlation were used to analyse data. Results indicated that the appropriateness of DoE to support Lean Six Sigma in various business activities (like finance, strategy and product development) has no relation to both product improvements through reformulation during product development and process optimisation using quality control tools. However, study participants provided a number of reasons for implementing DoE in the automotive component manufacturers. It is advised that the automotive component manufacturers develop a comprehensive variability reduction policy that aligns DoE tools to business performance.

\section{Introduction}

The Design of Experiment (DoE) is a powerful technique that studies the effect of several process parameters affecting the response or quality characteristic of a process or product (Johnson, Hutto, Simpson \& Montgomery 2012). It was developed in the early 1920s by Sir R.A. Fisher at the Rothamsted Agricultural Field Research Station in London, UK. His primary goal was to determine the optimum sunshine, water, amount of fertiliser and underlying soil condition needed to produce the best crop. After Fisher introduced the technique and demonstrated its use in agricultural experiments, much more research and development of DoE in the chemical industry followed (Johnson et al. 2012). Fisher's approach to DoE was a direct replacement of traditional one-variableat-a-time (OVAT) approach to experimentation. Sinha (2011) adds that the OVAT approach has limitations regarding experimentation. It lacks reproducibility, the interactions among the process parameters cannot be studied or analysed, there is a risk of arriving at the false optimum conditions for the process and it is not cost-effective but time-consuming in many cases.

Over the last 15 years, DoE has gained increased acceptance in the USA and Europe as an important tool for improving process capability, driving down quality costs and improving process yield (Steiner, MacKay \& Ramberg 2008). A number of successful applications of DoE for improving process performance, product quality and reliability, reducing process variability, improving process capability and developing new products have been reported by many manufacturers over a decade (Albin 2001; Antony 2001; Ellekjaer \& Bisgaard 1998; Green \& Launsby 1995; Sirvanci \& Durmaz 1993). DoE has gained increased attention among many Six Sigma practitioners as it is the key technique employed in the improvement phase of the Six Sigma methodology (Sinha 2011). Johnson et al. (2012) recommend that DoE be employed within the optimisation phase of Design for Six Sigma (DFSS). However, it must be indicated that DoE differs from observational statistical studies in that the factors of interest are controlled by the experimenter, rather than simply observed through the selection of randomised samples (Evans \& Lindsay 2011). It is a technique for developing reliable and robust products or processes in the 21st century (Laureani \& Antony 2012). Consequently, this article investigates the appropriateness of DoE as a management tool to support Lean Six Sigma in automotive component manufacturing companies of South Africa. Lean Six Sigma has over the 
years played a huge role in the manufacturing industry around the world (Aboelmaged 2010). Womack, Jones and Roos (1990) started the Lean movement and described Toyota's automotive approaches, which encompasses supplier and new product development issues. They also use the term Lean Production for the first time. For this article, Lean is defined as a philosophy designed to improve competitive advantage of the organisation by placing the customer at the heart of its processes and eliminating all non-value-adding activities. At around the same time, Lean was transforming the automotive world, and Six Sigma was gaining traction in a different market. In 1994 Larry Bossidy, CEO of Allied Signal, introduced the same techniques under the term Six Sigma as a business initiative to 'produce high-level results, improve work processes, expand all employees' skills and change the culture'. This was followed by the well-publicised implementation of Six Sigma at General Electric (Schroeder, Kevin, Charles, \& Adrian 2008). Within just a few years, Six Sigma had become a philosophy for business improvement within the industrial landscape. However, it was not long before the best of Lean was combined with the best of Six Sigma (Timans, Ahaus, van Solingen, Kumar \& Antony 2014). The phrase 'Lean Six Sigma' brought together these different approaches under one unifying umbrella of business improvement. On the same note, DoE, as introduced in the 1920s, was used as a test or a series of tests that enables the experimenter to compare two or more methods, thus determining better controllable factors that optimise the yield of a process or minimise variability of a response variable (Evans \& Lindsay 2011). It gained increased attention among many Six Sigma practitioners as a key technique that must be used in the improvement phase of the Lean Six Sigma methodology (Sinha 2011). However, Johnson et al. (2012) advised that DoE must be used during the optimisation phase of Lean Six Sigma. Hence, this article investigates the ability of DoE as a management tool to support Lean Six Sigma in the automotive component manufacturing companies of South Africa. It determines the reasons for management to implement DoE.

The remaining sections of this article discuss the literature review, research methodology, results, discussion and the implications of results for policy and practice, limitations, as well as the conclusion.

\section{Literature review}

This section discusses DoE as an approach to reduce variation. It elaborates on the framework of integrating DoE within Six Sigma framework.

\section{Overview of Design of Experiments as an approach to reduce variation}

There are many processes of interest in agriculture, industry and scientific studies for which experimentation is of high value. For these kinds of processes, experimentation is often the only possible way to understand the underlying mechanisms. The statistical techniques for designing and analysing such experiments may be very useful (Sinha 2011).
This is where DoE plays a crucial role. ADoE is a test or a series of tests that enables the experimenter to compare two or more methods (Evans \& Lindsay 2011). It determines the better or controllable factors in order to optimise the yield of a process or minimise the variability of a response variable. Evans and Lindsay (2011) add that DoE differs from observational statistical studies in that the factors of interest are controlled by the experimenter, rather than simply observed through the selection of randomised samples. Hence, DoE is recognised as an approach for improving the quality of the firm's product and service through variation reduction. It is an important tool available to the design and process engineers. As a result, the methodological tools of DoE have high utility in developing a quality product (Sinha 2011).

A notable development in DoE was when Sir R.A. Fisher, in the 1920s suggested ways to change more than one factor (synonymously, input or controllable variable) simultaneously, in contrast to changing one factor at a time (Steiner et al. 2008). The approach of changing one factor at a time may take an unnecessarily large number of experimental trials and may not give clear understanding of the interactions among the factors in the experiment. Consequently, DoE has gained increased acceptance as an efficient tool for improving process capability and yields (Steiner et al. 2008).

\section{Integration of Design of Experiments within Six Sigma framework}

Rapid globalisation of products and markets in the 21st century means that manufacturing competitiveness is increasing in every moment. In the present operational management environment, researchers have shown the importance of integrating a mix of different but overlapping manufacturing practices to achieve manufacturing competitiveness (Pullana, Bhasib \& Madhuc 2011). This includes integrating DoE within Six Sigma framework.

The Lean Production has received attention from academia and industry because of the significant achievements of a variety of manufacturing and service organisations within and outside the automobile industry (Hines, Holweg \& Rich 2004; Holweg 2007). According to Shah and Ward (2007), the main objective of Lean management is to eliminate waste by concurrently reducing or minimising supplier, customer and internal variability. Many of the tools (such as the Just-In-Time, OnePiece-Flow, 5S and Kaizen) of Lean were derived to minimise waste in the eyes of the customer. Lean thinking recognises that manufacturers can make significant progress by squeezing out the large number of non-value-added activities that are inherent in their processes. Thus, the Lean Six Sigma and Taguchi methods of DoE are based on the premise that waste is undesirable. Lean views waste as a by-product of failing to understand what constitutes 'value' to the customer (Shah \& Ward 2007). The philosophical elements of DoE view waste as a by-product of failing to produce a product (or design a process) that is robust against the variations of the environmental factors. Both methods originated in Japan, a society that does not tolerate waste (Bhasin \& Burcher 2006; Holweg 2007; Liker 2004). 
Surprisingly, very few studies look at how the Taguchi method of DoE could be integrated within a Lean manufacturing environment. A small electrical manufacturing company in Midwestern, United States, used DoE methods to reduce the waiting time and defects in the plasma-cutting machine. The Lean Six Sigma team which solved the problem also used the ' 5 whys' method to clear one of the major bottlenecks that keep the company away from moving towards the future state (Chen, Li \& Shady 2010). One of the leading forging companies in Eastern India used Taguchi DoE methods (i.e. the parameter design) to successfully map in Lean environment to minimise forging defects produced because of imperfect operating conditions, which were identified through the present and future states of value stream maps (Sahoo, Singh, Shankar \& Tiwari). Hence, this study investigates if DoE has the ability to support Lean Six Sigma in functional business activities (such as finance, strategy, product development, standardisation and customer service) in the automotive component manufacturing companies in South Africa.

\section{Methodology}

Four automotive component manufacturers in the eThekwini District Municipality in KwaZulu-Natal that uses Lean Six Sigma participated in the study. These companies have integrated a DoE strategy in their processes. Hence, this study investigates, via a survey using a questionnaire, if DoE is an appropriate tool to support Lean Six Sigma. It determines the reasons for management to implement DoE. The study assesses production and related experiences of the middle managers of the four participating companies. Descriptive and correlation analysis were used to analyse data. This section will be discussed under the following headings, namely research design and approach, the target population, sample size, data collection as well as measurement and data analysis.

\section{Research design and approach}

This study was quantitative in nature. Bryman and Bell (2007) explain that the quantitative approach involves the use of statistical procedures to analyse the data collected. Consequently, after the measurements of the relevant variables, the scores were transformed using statistical methods. The study was also conclusive in design. Conclusive studies are meant to provide information that is useful in reaching decision-making (Yin 2008).

\section{Target population}

Four automotive component manufacturers in the eThekwini District Municipality participated in the study. The target population comprised of 123 middle managers. These individuals were operating from either production or administrative sections of the companies.

\section{Sample size}

A simple random sampling technique was used to select the participants. A sample size of 107 middle managers participated in the study. This comprised of 79 middle managers from production and 28 from administration.

\section{Data collection}

The collection of data was achieved by physically distributing the questionnaires to the Human Resources department of participating companies. Similarly, the completed questionnaires were returned to the researcher via the Human Resource departments of the four participating companies. One hundred and seven questionnaires were returned, representing $86.9 \%$ response rate, considered high compared with the norm for survey responses (Baruch \& Holtom 2008). The main reason for this high response rate was because of the invitation letter sent to the participants and consistently following up the questionnaires through telephone calls.

\section{Measurement and data analysis}

In line with research framework, the study measured 15 variables using the questionnaire. It employed a Likert scale ranging from 1 (strongly agree) to 5 (strongly disagree). Descriptive and correlation analysis were used to test the two objectives.

\section{The ability of Design of Experiments as a management tool that supports Lean Six Sigma in various business activities}

The following variables measured the appropriateness of DoE to support Six Sigma in various business activities. These include the following:

- Finance: To help realise a Lean Six Sigma's Return on Investment (ROI). According to the Cambridge Dictionaries (2011), the ROI is the ratio between the net profit and cost on investment resulting from an investment of some resources. A high ROI means the investment's gains compare favourable to its cost.

- Strategy: To help Lean Six Sigma expedite problemsolving.

- Product development: To create confidence when new ideas are required from Lean Six Sigma.

- Standardisation: To help Lean Six Sigma standardise processes.

- Customer service: To help Lean Six Sigma improve quality of products.

\section{The reasons for management to implement Design of Experiments}

Thirteen items are listed in the questionnaire as the reasons for implementing DoE. These include to find the effects of variables when conducting a test, to take decisions involving unknowns, to determine the reasons of product rankings (i.e. the best product within product range), to reduce product variation, to assess the significance of the test results, to be convinced that certain product development actions are best, to optimise production costs, to make adjustments in order to improve performance, to solve production related problems when basic disciplines (like Lean Six Sigma) do not offer technical solution, to reduce product development time, to 
reduce process development time, to improve product reliability and to improve process capacity.

The Statistical Package for the Social Sciences (SPSS) version 23.0 was used to analyse data.

\section{Study results}

This section used correlation analysis to analyse variables relating to the appropriateness of DoE as a management tool to support Lean Six Sigma in various business activities. It also employed the descriptive analysis to determine the reasons why management implement DoE.

\section{The appropriateness of Design of Experiments to support Lean Six Sigma in various business activities}

The Pearson's correlation tests were used to find any significant relationship between study variables, which any two study variables are dependent or independent of each other, and to find the direction and strength of dependency (Cooper \& Emory 1995). Correlation can reveal the significance of correlation, if significant, whether it is positive or negative (direction of correlation) as well as the strength of the correlation.

The tests for significant relationships between the variables for the appropriateness of DoE to support Lean Six Sigma with the product and process performance were done in Table 1. The two performance variables include product improvement through reformulation during product development and process optimisation through quality control tools. These two variables were tested with DoE expected outcome variables in various business activities. They include the following:

- Finance: To help realise a Lean Six Sigma's ROI

- Strategy: To help Lean Six Sigma expedite problem-solving

- Product development: To bring confidence when new ideas are required from Lean Six Sigma

- Standardisation: To help Lean Six Sigma standardise processes

- Customer service: To help Lean Six Sigma improve quality of products.

Table 1 presents the analysis on the appropriateness of DoE to support Lean Six Sigma with product improvement through reformulation during product development and process optimisation using quality control tools.

The DoE variables in Table 1 do not statistically have a significant relationship with product improvement through reformulation during product development and process optimisation using quality control tools (at $p>0.05$ ). These include the expected outcomes for finance (to help realise a Lean Six Sigma's ROI), strategy (to help Lean Six Sigma expedite problem-solving), product development (to bring confidence when new ideas are required from Lean Six Sigma), standardisation (to help Lean Six Sigma standardise processes) and customer service (to help Lean Six Sigma improve quality of products).

\section{The reasons for management to implement Design of Experiments}

The study has used the descriptive statistics to analyse the reasons for management to implement DoE. Table 2 presents the reasons for management to implement DoE.

Table 2 provided high percentage response rates from middle managers in the automotive component manufacturing companies on the reasons to implement DoE. The highest reasons that range from $80 \%$ to $94.45 \%$ include to find the effects

TABLE 2: Reasons for management to implement Design of Experiments.

\begin{tabular}{ll}
\hline Variables & $\begin{array}{c}\text { Middle managers' response } \\
\text { accepting this perception (\%) }\end{array}$ \\
\hline To find the effects of variables when conducting a test & 88.0 \\
To take decisions involving unknowns & 70.1 \\
\hline $\begin{array}{l}\text { To determine the reasons of product rankings (i.e. the } \\
\text { best product within product range) }\end{array}$ & 57.0 \\
To reduce product variation & 89.7 \\
\hline $\begin{array}{l}\text { To assess the significance of test results } \\
\text { To be convinced that certain product development }\end{array}$ & 86.0 \\
actions are best & 54.2 \\
\hline $\begin{array}{l}\text { To optimise production costs } \\
\text { To make production adjustments in order to improve } \\
\text { performance }\end{array}$ & 87.9 \\
$\begin{array}{l}\text { To solve production related problems when basic } \\
\text { disciplines (like Lean Six Sigma) do not offer technical } \\
\text { solutions }\end{array}$ & 94.4 \\
\hline $\begin{array}{l}\text { To reduce product development time } \\
\text { To reduce process development time }\end{array}$ & 62.6 \\
\hline $\begin{array}{l}\text { To improve product reliability } \\
\text { To improve process capability }\end{array}$ & 57.9 \\
\hline
\end{tabular}

Source: Data from research survey

TABLE 1: The appropriateness of Design of Experiments to support Lean Six Sigma and product improvement through reformulation during product development.

\begin{tabular}{|c|c|c|c|c|}
\hline \multirow{2}{*}{$\begin{array}{l}\text { Variables in different } \\
\text { business activities }\end{array}$} & \multirow[t]{2}{*}{ Variables } & \multirow{2}{*}{$\begin{array}{l}\text { Statistical } \\
\text { tests used }\end{array}$} & \multicolumn{2}{|c|}{ Correlation } \\
\hline & & & $\begin{array}{l}\text { Product improvement through } \\
\text { reformulation during product development }\end{array}$ & $\begin{array}{l}\text { Process optimisation using quality control } \\
\text { tools such as statistical process control }\end{array}$ \\
\hline Finance & To help realise a Lean Six Sigma's ROI & Sig. (2 tailed) & $\begin{array}{l}0.050 \\
0.608\end{array}$ & $\begin{array}{l}0.097 \\
0.320\end{array}$ \\
\hline Strategy & $\begin{array}{l}\text { To help Lean Six Sigma expedite problem- } \\
\text { solving }\end{array}$ & Sig. (2-tailed) & $\begin{array}{l}0.060 \\
0.542\end{array}$ & $\begin{array}{l}0.051 \\
0.603\end{array}$ \\
\hline $\begin{array}{l}\text { Product } \\
\text { development }\end{array}$ & $\begin{array}{l}\text { To bring confidence when new ideas are } \\
\text { required from Lean Six Sigma }\end{array}$ & Sig.(2 tailed) & $\begin{array}{l}-0.075 \\
0.443\end{array}$ & $\begin{array}{l}0.129 \\
0.185\end{array}$ \\
\hline Standardisation & $\begin{array}{l}\text { To help Lean Six Sigma standardise } \\
\text { processes }\end{array}$ & Sig. (2-tailed) & $\begin{array}{l}-0.062 \\
0.527\end{array}$ & $\begin{array}{l}0.095 \\
0.332\end{array}$ \\
\hline Customer service & $\begin{array}{l}\text { To help Lean Six Sigma improve the quality } \\
\text { of products }\end{array}$ & $\begin{array}{l}\text { Correlation } \\
\text { Sig. (2-tailed) }\end{array}$ & $\begin{array}{l}-0.051 \\
0.601\end{array}$ & $\begin{array}{l}0.126 \\
0.196\end{array}$ \\
\hline
\end{tabular}


of variables when conducting a test, to reduce product variation, to assess the significance of the test results, to optimise production costs, to make production adjustments in order to improve performance and to improve process capability.

\section{Discussions}

The main objective of the study was to investigate, via a survey using a questionnaire, if DoE is an appropriate tool to support Lean Six Sigma. It assesses the reasons for management to implement DoE. The results indicate that the appropriateness of DoE to support Lean Six Sigma in various business activities has no relation to both product improvements through reformulation during product development and process optimisation using quality control tools. These include finance (to help realise a Lean Six Sigma's ROI), strategy (to help Lean Six Sigma expedite problem-solving), product development (to bring confidence when new ideas are required from Lean Six Sigma), standardisation (to help Lean Six Sigma standardise processes) and customer service (to help Lean Six Sigma improve quality of products). Steiner et al. (2008) indicate that Six Sigma is valuable for many types of industrial problems and is appropriate for integration with other process improvement methodologies. However, the Six Sigma tools are neither novel nor necessarily the best.

On the contrary, the study established a number of reasons for implementing DoE in the automotive component manufacturing companies. Key factors include DoE as a management tool that helps to find the effects of variables when conducting a test, reduces product variation, assesses the significance of test results, optimises production costs, makes adjustments in order to improve performance and improves process capability. The highest percentage response rate ranges from $80 \%$ to $94.45 \%$. This indicates that middle managers in the automotive component manufacturers were optimistic about the benefits from DoE. This has been confirmed by Steiner et al. (2008). They indicated that, over the years, DoE has gained increased acceptance in the USA and Europe as an important ingredient for improving process capabilities, driving down quality costs and improving process yield.

\section{Implications of results for policy and practice}

DoE methods have achieved considerable success in many industries (Evans \& Lindsay 2011). However, this research produced mixed results. DoE's ability to support Lean Six Sigma has no relations to both product improvements through reformulation and process optimisation using quality control tools. The automotive component manufacturing companies must develop a comprehensive variability reduction policy that aligns DoE tools to business performance. During the course of the study, management provided a number of reasons why they have implemented DoE. These include (among others) the following:

- to reduce product variation

- to optimise production costs

- to make production adjustments in order to improve performance.

\section{Study limitations}

The study was limited to the automotive component manufacturing industry within the eThekwini District Municipality. The investigation was conducted in four companies that have adopted DoE. Hence, the result cannot be generalised to companies operating in other industrial sectors.

\section{Conclusion}

In order to maximise performance, a comprehensive variability reduction policy must be developed, which aligns DoE tools to business performance. Although the study indicated that the DoE variables for finance, strategy, product development, standardisation and customer service lack appropriateness to support Lean Six Sigma in the automotive component manufacturing companies of South Africa, management listed various benefits they get by implementing DoE tools. These include DoE as a management tool that helps to find the effects of variables when conducting a test, reduces product variation, assesses the significance of test results, optimises production costs, makes adjustments in order to improve performance and improves process capability. Middle managers in the automotive component manufacturers were optimistic about the benefits from DoE.

\section{Future research required}

The nature of this study did not allow the investigation to determine the long-term DoE survival to a wider sector of the economic activity. It was limited to the automotive component manufacturers within the eThekwini District Municipality in KwaZulu-Natal. Only four companies that have adopted DoE participated in the study. It is recommended that future studies examine the following issues in greater depth: (1) when to use and when not to use a DoE system, and (2) the applicability of DoE to other industrial sectors.

\section{Acknowledgements Competing interests}

The authors declare that they have no financial or personal relationships which may have inappropriately influenced them in writing this article.

\section{References}

Aboelmaged, M.G., 2010, 'Future research', International Journal of Quality and Reliability Management 27(3), 268-317.

Albin, D., 2001, 'The use of statistical experimental design for PCB process optimization', Circuit World 27(4), 12-15. https://doi.org/10.1108/03056120110398191

Antony, J., 2001, 'Improving the manufacturing process quality using design of experiments: A case study', International Journal of Operations and Production Management 21(6), 812-822. https://doi.org/10.1108/01443570110390499

Baruch, Y. \& Holtom, B.C., 2008, 'Survey response rate levels and trends in organizational research', Human Relations 61(8), 1139-1160. https://doi. org $/ 10.1177 / 0018726708094863$

Bhasin, S. \& Burcher, P., 2006, 'Lean viewed as a philosophy', Journal of Manufacturing TechnologyManagement 17(1),56-72.https://doi.org/10.1108/17410380610639506

Bryman, A. \& Bell, E., 2007, Business research methods, Oxford Press, New York City: USA.

Cambridge Dictionaries. 2011, Financial Indicator, Cambridge University Press, Cambridge, viewed 10 May 2018, from http://dictionary.cambridge.org/ dictionary/business-english/financialindicator?Q1/1/4inancialindicator 
Chen, J.C., Li, Y. \& Shady, B.D., 2010, 'From value stream mapping toward a lean/ sigma continuous improvement process: An industrial case study', International
Journal of Production Research 48(4), 1069-1086. https://doi.org/10.1080/ Journal of Production

Cooper, D.R. \& Emory, C.W., 1995, Business research methods, 5th edn., McGraw Hill, New York City: USA.

Ellekjaer, M.R. \& Bisgaard, S., 1998, 'The use of experimental design in the development of new products', International Journal of Quality Science 3(3), 254-274. https://doi.org/10.1108/13598539810229230

Evans, J.R. \& Lindsay, W.M., 2011, The management and control of quality, 8th edn. Library of Congress, Washington DC: USA.

Green, T.J. \& Launsby, R.G., 1995, 'Using DOE to reduce costs and improve the quality of microelectronic manufacturing processes', International Journal of Microelectronics and Electronic Packaging 18(3), 290-296.

Hines, P., Holweg, M. \& Rich, N., 2004, 'Learning to evolve: A review of contemporary lean thinking', International Journal of Operations and Production Management 24(10), 994-1011. https://doi.org/10.1108/01443570410558049

Holweg, M., 2007, 'The genealogy of lean production', Journal of Operation Management 25(6), 420-437. https://doi.org/10.1016/j.jom.2006.04.001

Johnson, R.T., Hutto, G.T., Simpson, J.R. \& Montgomery, D.C., 2012, 'Designed experiments for the defence community', Quality Engineering 24(1), 60-79. https://doi.org/10.1080/08982112.2012.627288

Laureani, A. \& Antony, J., 2012, 'Critical success factors for the effective implementation of Lean Sigma: Results from an empirical study and agenda for future research International Journal of Lean Six Sigma 3(4), 274-283. https://doi.org/ $10.1108 / 20401461211284743$

Liker, J.K., 2004, The Toyota Way - Fourteen management principles from the world's greatest manufacturer, McGraw-Hill, London.
Pullana, T.T., Bhasib, M. \& Madhuc, G., 2013, 'Decision support tool for lean product and process development, Production Planning and Control', The Management of Operations 24(6), 449-464. https//doi.org/10.1080/09537287.2011.633374

Sahoo, A.K., Singh, N.K., Shankar, R. \& Tiwari, M.K., 2007, 'Lean philosophy: Implementation in a forging company', The International Journal of Advanced Manufacturing Technology 36(5-6), 451-462. https://doi.org/10.1007/s00170-006-0870-2

Schroeder, R., Kevin, L., Charles, L. \& Adrian, C., 2008, 'Six Sigma: Definition and underlying theory', Journal of Operations Management 26(4), 536-554. https:// doi.org/10.1016/j.jom.2007.06.007

Shah, R. \& Ward, P.T., 2007, 'Defining and developing measures of lean production', Journal of Operations Management 25(4), 785-805. https://doi.org/10.1016/j. jom.2007.01.019

Sinha, P., 2011, 'A search method for process optimization with designed experiments and e observations', International Journal of Quality and Reliability Management 28(5), 503-518. https://doi.org/10.1108/02656711111132553

Sirvanci, M.B. \& Durmaz, M., 1993, 'Variation reduction by the use of designed experiments', Quality Engineering 5(4), 611-618. https://doi.org/10.1080/ 08982119308919003

Steiner, S.H., MacKay, R.J. \& Ramberg, J.S., 2008, 'An overview of the Shainin system for quality improvement', Quality Engineering 20(1), 6-99. https://doi.org/ 10.1080/08982110701648125

Timans, W., Ahaus, K., van Solingen, R., Kumar, M. \& Antony, J., 2014, 'Implementation of continuous improvement based on Lean Six Sigma in small and medium sized enterprises', Total Quality Management and Business Excellence Journal, viewed 10 May 2018, from http://doi.org/10.1080/14783363.2014.980140

Womack, J.P., Jones, D.T. \& Roos, D., 1990, Machine that changed the world, Simon \& Schuster, London, UK.

Yin, R.K., 2008, Handbook of applied research, California, Sage, Thousand Oaks, CA. 